\title{
Communication
}

\section{Laurence McKeown}

Long Kesh

For ages

our bodies kept apart

we touched one another with our words

written small but caressingly

we made love from a distance.

The words

chosen carefully, thoughtfully

took the form of lips

or of tongue

now a hug, a kiss, an embrace

now two bodies entwined.

And I wondered how literate I was

and if my movements were clumsy.

Did an elbow jar you?

A verb or adjective cause you pain?

It's difficult to affix to paper

an expression

or write a smile which speaks in silence

words of intensity.

Yet together

we've shaped over time

fingers from our words

and our sentences

are as hands which reach out

to hold, to embrace, to touch.

For ages now

though we're apart

we've touched one another with our words

written small but caressingly

we've made love from a distance. 